\title{
MAUS-TRATOS DE ANIMAIS: \\ UMA PROTEÇÃO SIMBÓLICA \\ NA LEI DE CRIMES AMBIENTAIS*
}

\author{
Karen Teixeira***
}

\section{INTRODUÇÃO}

0 presente estudo tem por objetivo analisar a aplicação da punição prevista no art. 32 da Lei de Crimes Ambientais, imposta a quem praticar maus-tratos ou atos de abuso contra animais. Referida norma decorre diretamente do mandamento constante no art. 225, §1ํㅡㄹ inciso VII da Constituição Federal de 1988, que determina a proteção da fauna e veda a crueldade contra os animais.

Desta maneira, ao inserir no texto constitucional uma proibição relacionada ao sofrimento animal, o legislador demonstrou, mesmo que de forma singela, que o Direito deve preocupar-se não apenas com a vida, mas também com a integridade física dos animais.

Como forma de tutelar o meio ambiente, tido como bem fundamental à sobrevivência humana, e estando nele inclusas a fauna e a flora, o legislador também previu a criminalização das lesões ao bem ambiental, razão pela qual, visando a complemen-

\footnotetext{
* Artigo apresentado ao Curso de Bacharelado em Direito do Centro Universitário Metodista - IPA, como requisito parcial para obtenção do Grau de Bacharel em Direito. Orientador: Prof. Dr. Rogério Rammê.

** Bacharela em Direito pelo Centro Universitário Metodista - IPA.
} 
tação da norma constitucional, a Lei de Crimes Ambientais foi editada, em 1998.

Nesse contexto, formula-se o problema de pesquisa que norteou o presente trabalho: a Lei de Crimes Ambientais surgiu a partir das disposições protecionistas ao meio ambiente trazidas pela Constituição Federal de 1988. Dentre outras previsões constantes na Lei, observa-se a imposição de punição para aqueles que cometam atos de maus-tratos contra animais silvestres, domésticos ou domesticados (art. 32 da Lei no 9.605/98). Entretanto, apesar da existência de tipo penal específico que comina pena repressiva àqueles que pratiquem o referido crime, é possível afirmar que há efetividade na repressão penal desse delito?

As hipóteses inicialmente formuladas para a pesquisa são as seguintes: (a) devido à predominância do entendimento civilista que classifica o animal como coisa passível de apropriação (art. 82 do CC), a tendência cultural dominantefaz com que os proprietários de animais acreditem poder utilizar-se desses seres da forma como entenderem mais adequada, não sendo, muitas vezes, respeitadas por eles as previsões legais de vedação a maus-tratos, seja por desconhecimento, seja pela desconsideração do valor intrínseco da vida animal; (b)a Lei no 9.605/98, criada para tipificar condutas lesivas ao meio ambiente, previu em seu art. 32 uma punição para aqueles que maltratarem os animais. Contudo, tal artigo não é claro ao determinar quais práticas são entendidas como maus-tratos, o que acarreta em um vazio normativo (norma penal em branco) que dificulta a repressão penal de muitas condutas abusivas e cruéis contra os animais não humanos; (c) o legislador, ao editar a Lei de Crimes Ambientais, previu que a pena para a prática do crime de maus-tratos contra animais deve ser de detenção de 3 meses a 1 ano, cumulada com multa. Contudo, tendo em vista que, além de o instituto da detenção ser menos rigoroso e não admitir regime inicial fechado, a pena mínima é inferior a 1 ano, o que permite, de acordo com a Lei $n^{0}$ 
9.099/95, o oferecimento, pelo Ministério Público, de suspensão condicional do processo, o qual acarreta uma despenalização. Ou seja, não se alcança, mesmo na hipótesede condenação, uma resposta penal adequada capaz de dissuadir à prática delitiva; e (d) a visão antropocêntrica do direito ambiental brasileiro, caracterizada pela preocupação exclusiva com o bem-estar dos seres humanos, não alcança, sobretudo na esfera penal, uma tutela efetiva dos animais individualmente considerados, já que nos crimes contra a fauna, de modo geral, a sociedade é tida como a vítima do delito e não o animal que sofreu a violência.

A narrativa foi estruturada da seguinte forma: na primeira etapa discorrer-se-á sobre os principais aspectos da tutela jurídico-penal dos animais no Direito brasileiro, com ênfase no crime de maus tratos aos animais e sob a perspectiva constitucional. $\mathrm{Na}$ segunda etapa, buscar-se-á analisar os principais aspectos que, hipoteticamente, tornam o crime de maus-tratos aos animais uma proteção simbólica na Lei de Crimes Ambientais.

Trata-se de pesquisa qualitativa, que se utilizou de dados documentais, doutrinários e jurisprudenciais referentes ao tema da pesquisa. 0 método de pesquisa utilizado foi o hipotético-dedutivo.

Cabe ressaltar que a discussão é extremamente atual e se justifica principalmentequando verificados os inúmeros casos veiculados nas mídias sociais envolvendo agressão, abandono e trato cruel, que resultam, muitas vezes, no óbito de animais.

Importa salientar, também, que o enfoque principal da pesquisa é a prática do crime de maus-tratos contra animais domésticos, uma vez que estes, estando na condição de "propriedade particular", estão mais suscetíveis a abusos.

Almeja-se com o presente trabalho, contribuir na caminhada por novos ares de compreensão acerca dos problemas que fragilizam uma adequada tutela dos animais no Direito brasileiro, evidenciando que, em que pese existam normas nos âmbitos cons- 
titucional e penal que tratem da tutela dos animais no Brasil,ainda há grande fragilidade na proteção destinada a esses seres.

\section{A TUTELA JURÍDICA DOS ANIMAIS NO DIREITO BRASILEIRO}

O surgimento da proteção animal em âmbito constitucional trouxe ao Direito uma nova dimensão do direito fundamental à vida. A Constituição Federal de 1988, embora não tenha sido a primeira norma brasileira a proteger a fauna, é um marco para o pensamento sobre os direitos animais no Brasil. Ao proibir a crueldade, a Constituiçãoreconhece aos animais o direito de ter respeitado o seu valor intrínseco, sua integridade e sua liberdade. Contudo, o ordenamento jurídico brasileiro, ainda enraizado a ideias e tradições ultrapassadas, enfrenta dificuldades em refletir sobre as mudanças sociais, considerando, por vezes, apenas os desejos dos donos dos animais, classificados comores para o direito civil brasileiro ${ }^{1}$.

Essa visão antiquada também afeta diretamente a tutela penal dos animais, que possui previsões específicas, principalmente na Lei de Crimes Ambientais. Isso porque, quando não considerada a dignidade da vida animal, sobram obstáculos para garantir a efetividade da Lei.

A discussão relacionada à proteção animal, no entanto, tem se destacado dentre todas as pautas relacionadas ao meio ambiente, uma vez que a interação entre espécies animais e o ser humanotem ocorrido cada vez mais, de diversasformas e intensidades ${ }^{2}$.

MEDEIROS, Fernanda Luiza, Fontoura de; WEINGARTNER NETO, Jayme; PETTERLE, Selma Rodrigues. Animais não-humanos e vedação de crueldade: o STF no rumo de uma jurisprudência intercultural. Canoas, RS: Ed. Unilasalle, 2017, p. 72-73.

2 MEDEIROS, Fernanda Luiza, Fontoura de; WEINGARTNER NETO, Jayme; PETTERLE, Selma Rodrigues. Animais não-humanos e vedação de crueldade: o STF no rumo de uma jurisprudência intercultural. Canoas, RS: Ed. Unilasalle, 2017, p. 85. 
O tema é, de fato, apaixonante, principalmente porque são poucas as pessoas que não convivem com esses seres vivos, seja em relações de amor, seja em relações de tolerância, ou, ainda,em relações de ódio, o que ocorre, não raras vezes, em razão da falta de compreensão do papel por eles desempenhado no mundo e na qualidade de vida dos seres humanos ${ }^{3}$.

Dentro do assunto, chama atenção a crescente comoção e empatia pelos animais domésticos, visto que estes estão cada vez mais presentes no convívio com os seres humanos e, em consequência dessa proximidade, tornam-se extremamente vulneráveis a abusos e maus-tratos, tema que será abordado de modo mais específico nos itens a seguir.

\subsection{ASPECTOS CONSTITUCIONAIS RELACIONADOS À PROTEÇÃO ANIMAL}

A fauna brasileira, composta por animais nativos, silvestres, exóticos, domésticos e domesticados, é mencionada algumas vezes no texto da Constituição Federal de 1988. A competência para sua preservação está prevista no art. 23, inciso VII, do texto constitucional, sendo esta de responsabilidade comum entre União, Estados, Distrito Federal e Municípios. Também, o art. 24, inciso VI, dispõe que é competência concorrente da União, dos Estados e do Distrito Federal legislar sobre a caça, a pesca e a fauna, podendo os Municípios legislarem de forma suplementar e conforme os interesses locais. Desses artigos, portanto, é possível extrair que todos os entes políticos possuem alguma competência - e, consequentemente, responsabilidades - quando se trata da proteção dos animais.

0 artigo 225, § 1ํㅡㄹ inciso VII, da Constituição Federal, por sua vez, traz a mais importante previsão relacionada à proteção da fauna, visto que proíbe expressamente as práticas que coloquem

CASTRO, João Marcos Adede y. Direito dos animais na legislação brasileira. Porto Alegre: Sergio Antonio Fabris Ed., 2006, p. 35. 
em risco a função ecológica, provoquem a extinção de espécies ou submetam os animais à crueldade, atribuindo ao Poder Público a garantia dessa proteção. Sobre essa disposição, entendem alguns autores que, por se tratar de norma constitucional de eficácia plena, esta independe de regulamentação ${ }^{4}$. No entanto, com relação à proteção animal, uma série de normas infraconstitucionais regulamentam o texto constitucional, como a Lei $\mathrm{n}^{0}$ 12.651/12 (Código Florestal), a Lei no 9.985/00 (SNUC) e a Lei no 9.605/98 (Lei de Crimes Ambientais) ${ }^{5}$.

Sobre a tutela constitucional dos animais, merece destaque a posição de Fernanda Luiza Fontoura de Medeiros, Jayme Weingartner Neto e Selma Rodrigues Petterle ${ }^{6}$ :

A Constituição brasileira de 1988 foi vanguardista ao estabelecer um capítulo especifico à proteção do ambiente e avançou, ainda mais, ao estabelecer uma corajosa proteção aos animais pois, pela primeira vez,foi reconhecida constitucionalmente uma norma de proteção à vida dos animais.Além disso, para além do fato de proteger a vida, se buscou, simplesmente, garantir a vedação de maus tratos e a vedação à crueldade.

Luiz Regis Prado $^{7}$, sobre a redação do art. 225, afirma que "o texto constitucional abarca todos os animais irracionais, independentemente de sua função ecológica, de sua nacionalidade ou do seu risco de extinção". Ainda segundo o autor, a proteção constitucional dos animais domésticos e dos animais selvagens

4 AMADO, Frederico Augusto Di Trindade. Direito ambiental esquematizado. $7^{\mathrm{a}}$ ed. rev. e atual. Rio de Janeiro: Ed. Forense. São Paulo, Ed. Método, 2016, p. 425.

5 SILVA, Romeu Faria Thomé da. Manual de direito ambiental. 6a ed. rev. ampl. e atual. Salvador: Ed. JusPODIVM, 2016, p. 144.

6 MEDEIROS, Fernanda Luiza, Fontoura de; WEINGARTNER NETO, Jayme; PETTERLE, Selma Rodrigues. op. cit., p. 85.

7 SILVA, Romeu Faria Thomé da. op. cit., p. 227. 
obedecem a distintas a finalidades: "Trata-se de preservar os primeiros de atos de crueldade e do abandono e de proteger os segundos de uma captura, destruição, comercialização desenfreada e que os tornam particularmente vulneráveis".

Nesse sentido, verifica-se que acertou o legislador quando abriu espaço para os animais domésticos na norma constitucional, tendo em vista que o fato de não correrem risco de extinção não significa que deixem de ser integrantes do meio ambiente e essenciais à qualidade de vida ${ }^{8}$. Mas, aquele que talvez seja o principal avanço que a Constituição Federal de 1988 provocou na tutela dos animais, mesmo daqueles que não desempenhem um papel ecológico significativo - caso dos animais domésticos e domesticados - seja o reconhecimento, mesmo que implícito, de um conteúdo de dignidade à vida animal, o qual justifica a vedação de que qualquer animal seja tratado com crueldade. ${ }^{9}$

Celso Antônio Pacheco Fiorillo segue a mesma linha de raciocínio quando afirma que a tutela constitucional ambiental preocupa-se com a vida, em todas as suas formas ou manifestações ${ }^{10}$.

Assim, pode-se concluir, neste ponto, que independentemente de repartição de competências, incumbe ao Estado a tutela dos animais,sem distinções em razão de sua função ecológica, sendo-lhes garantida proteção jurídico-constitucional.

8 TOLEDO, Maria Izabel Vasco de. A tutela jurídica dos animais no Brasil e no direito comparado. Revista Brasileira de Direito Animal, vol. 11, p. 5, jul-dez. 2012. Disponível em: <https://portalseer.ufba.br/index.php/RBDA/article/ view/8426> Acesso em 23.mai.2017.

9 A esse respeito, destaca-se a posição de Medeiros, Weingartner Neto e Petterle: "Há, portanto, um âmbito normativo concreto, qual seja, a expressa manifestação, constante na Constituição brasileira, que também protege um conteúdo de dignidade com relação à vida dos animais, que não podem ser tratados com crueldade. Este conteúdo (de tratar animais com crueldade) é uma instrumentalização proibida pela Constituição. Por óbvio que essa norma proibitiva não exclui outro problema, que é o de saber, afinal de contas, o que é crueldade, missão sem dúvida árdua." MEDEIROS, Fernanda Luiza, Fontoura de; WEINGARTNER NETO, Jayme; PETTERLE, Selma Rodrigues. op. cit., 2017, p. 20.

10 FIORILlo, Celso Antônio Pacheco; CONTE, Christiany Pegorari. Crimes Ambientais. São Paulo: Ed. Saraiva, 2012, p. 16. 


\subsection{CONSIDERAÇÕES INICIAIS SOBRE A TUTELA DOS ANIMAIS PELO DIREITO PENAL AMBIENTAL}

$\mathrm{O}$ direito fundamental ao meio ambiente ecologicamente equilibrado, bem de uso comum do povo e essencial à sadia qualidade de vida ${ }^{11}$, está previsto no art. 225, caput, da Constituição Federal brasileira.Com a previsão de um capítulo constitucional dedicado à a proteção ambiental, o meio ambiente ecologicamente equilibrado passou a integrar um rol de bens jurídicos fundamentais e, a partir dessa classificação, merecedor de proteção penal ${ }^{12}$.

A proteção do meio ambiente é fundamental para a sobrevivência dos seres humanos das presentes e futuras gerações, razão pela qual o legislador inseriu, no artigo 225 , §3ํㅡㄹ da Constituição Federal, a possibilidade de responsabilização criminal por atos lesivos ao meio ambiente, independentemente de aplicação de sanções administrativas ou reparação de danos na esfera cível. Nas palavras de Luiz Regis Prado, o texto constitucional assinala a necessidade de proteção jurídico-penal do meio ambiente, com a obrigação ou mandato expresso de criminalização ${ }^{13}$.

Porém, em que pese a Constituição Federal imponha a aplicação de medidas coercitivas aos transgressores do mandamento constitucional de proteção ao meio ambiente ${ }^{14}$, o direito penal deve ser utilizado como ultimaratio, o que significa dizer que cabe ao legislador ordinário precisar se a conduta provoca lesão ou perigo penalmente relevante ao meio ambiente ${ }^{15}$.

11 Art. 225. Todos têm direito ao meio ambiente ecologicamente equilibrado, bem de uso comum do povo e essencial à sadia qualidade de vida, impondo-se ao Poder Público e à coletividade o dever de defendê-lo e preservá-lo para as presentes e futuras gerações.

12 SILVA, Ivan Luiz da. Princípio da insignificância e os crimes ambientais. Rio de Janeiro: Ed. Lumen Juris, 2008, p. 65.

13 PRADO, Luiz Regis. Direito penal do ambiente. - 5a ed. rev., atual. e ampl. São Paulo: Ed. Revista dos Tribunais, 2013, p. 79.

14 Ibid., p. 80.

15 Ibid., p. 79 
Nas palavras de Ivan Luiz da Silva ${ }^{16}$, o direito penal deve atuar como última instância de proteção aos bens imprescindíveis à sociedade, ou seja, só caberá a tutela penal quando todos os outros meios de proteção - cíveis e administrativos -, se mostrarem insuficientes à guarda dos bens tutelados, tendo em vista que a sanção penal é a intervenção estatal mais gravosa do ordenamento jurídico.Assim, compreende-se que a defesa penal do bem jurídico somente ocorrerá se houver formas de agressão ou ataque consideradas mais graves ou socialmente intoleráveis contra bens fundamentais ${ }^{17}$.

Entretanto, se analisada a questão por outro viés, a aplicação do direito penal na proteção do meio ambiente - mesmo que como ultimaratio - traz alguns benefícios em comparação ao direito civil, uma vez que a sanção penal, que possui função de prevenção geral e especial, gera consequências morais e sociais de extrema relevância ${ }^{18}$, e que podem implicar, de maneira mais eficiente, na coibição de atos lesivos a esse bem jurídico.

A referida função de prevenção caracteriza-se pelo desejo de criar um sentimento de intimidação, por meio de uma sanção, para que se evite a conduta proibida. Falhando a intimidação, o condenado terá sobre si a execução de sentença penal condenatória para fins de ressocializá-lo ou neutralizá-lo ${ }^{19}$.

Sobre a tutela penal, Ivan Luiz da Silva ${ }^{20}$ explica que a aplicação desta é definida pela relevância social do bem jurídico protegido, a qual serve como base de legitimação para o estabelecimento de sanções aplicáveis às ofensas a esse bem.

\footnotetext{
16 SILVA, Ivan Luiz da. op. cit., p. 67.

17 PRAD0, Luiz Regis. op. cit., p. 100.

18 SAnTIAGO, Alex Fernandes. Fundamentos de Direito Penal Ambiental. Belo Horizonte: Ed. Del Rey, 2015, p. 88.

19 SILVA, Ivan Luiz da. op. cit., p. 71 apud TOLEDO, Francisco de Assis. Princípios básicos de direito penal. 5a ed., São Paulo: Ed. Saraiva, 2000, p. 3.

20 SILVA, Ivan Luiz da. op. cit., p. 64.
} 
Deste modo, considerando que a Constituição Federal é, a princípio, a fonte dos bens jurídicos suscetíveis de tutela penal, uma vez que nela estão dispostos os valores ético-sociais elementares da sociedade ${ }^{21}$, e havendo previsão constitucional de um dever de proteção da fauna, independentemente de sua função ecológica, tem-se que esse mandamento deve ser respeitado e garantido.

0 que se vê, no entanto, é que o direito penal ambiental no Brasil, na prática, ainda se pauta em um paradigma antropocêntricoque acarreta, como corolário, uma tutela jurídica dos animais não de forma individualizada, mas de forma ampla, como membros integrantes do macrobem "fauna", importantes para o equilíbrio do meio ambiente e, em especial, à sadia qualidade de vida do ser humano. Assim, pela perspectiva do direito penal ambiental, entende-se que o bem jurídico a ser tutelado é o meio ambiente, sendo os animais não-humanos meros objetos materiais dos delitos ${ }^{22}$. Entretanto, estará correta esta perspectiva - antropocêntrica - que predomina no direito penal ambiental, ou será possível questionar a dogmática jurídico-penal neste particular, reconhecendo a possibilidade de se atribuir ao animal a titularidade de bens jurídicos penais específicos?

Antes, porém, de avançar sobre essa tormentosa questão, cumpre salientar que para fins de regulamentar a norma constitucional que prevê a tutela penal do meio ambiente - inclusa, aqui, a tutela penal dos animais -, em 12 de fevereiro de 1988 foi editada a Lei no 9.605, denominada "Lei de Crimes Ambientais". Observe-se nem todos os crimes ambientais estão previstos na Lei de Crimes Ambientais, contudo, essa é a principal lei brasileira que trata da tutela penal do meio ambiente, pois sistematiza, em sua redação, sanções penais e administrativas consequentes de condutas ou práticas que provoquem lesões a esse bem jurídico.

${ }^{21}$ SILVA, Ivan Luiz da. op. cit., p. 64 apud TOLEDO, Francisco de Assis. Princípios básicos de direito penal. 5a ed., São Paulo: Ed. Saraiva, 2000, p. 16.

22 TOLEDO, Maria Izabel Vasco de. op. cit., p. 6. 
Nada obstante, para que se compreenda a efetividade dos dispositivos da referida norma, é necessário, primeiramente, analisar as formas de aplicação de suas penalidades.

Da leitura do texto legal, é possível verificar que o legislador preocupou-se em dividir os tipos penais em seis partes, da seguinte maneira: crimes contra a fauna (do art. 29 ao 37), crimes contra a flora (do art. 38 ao 53), poluição e outros crimes ambientais (do art. 54 ao 61), crimes contra o ordenamento urbano e o patrimônio cultural (do art. 62 ao 65) e os crimes contra a Administração Ambiental (do art. 66 ao 69-A).

No que tange à aplicação das sanções penais resultantes das condutas previstas nos artigos supramencionados, as disposições encontram-se entre os artigos 6ำ e 24 da referida Lei.Porém, especificamente com relação aos crimes praticáveis contra animais domésticos, importa a análise das disposições a seguir.

0 art. $6^{0}$ da Lei, como regra geral, prevê que, para a imposição de penalidades, deverão ser observados: a gravidade do fato, os antecedentes do infrator em matéria ambiental e a sua situação econômica, no caso de aplicação de pena de multa.

Uma vez determinada a pena, desde que inferior a 4 anos, essa pode ser substituída, mesmo nos casos de crimes dolosos, observando, também, que a reincidência não aparece como obstáculo à substituição na Lei 9.605/9823, embora haja maior censurabilidade de quem reincide ${ }^{24}$.

Nesse sentido, sobre as penalidades aplicáveis, os artigos 7ํㅜ e 8o estabelecem que as penas restritivas de direitos, quais sejam, prestação de serviços à comunidade, interdição temporária de direitos, suspensão parcial ou total de atividades, prestação pecuniária e recolhimento domiciliar, são autônomas e podem ser substitutas das penas privativas de liberdade, nos casos em que o crime for culposo ou que a pena privativa de liberdade

${ }^{23}$ FIORILLO, Celso Antônio Pacheco; CONTE, Christiany Pegorari. op. cit., p. 50. 24 Ibid., p. 57. 
aplicada seja inferior a quatro anos, bem como quando analisado que a substituição é suficiente para efeitos de reprovação e prevenção do crime.

Aqui é importante mencionar que boa parte das penalidades previstas na Lei de Crimes Ambientais não ultrapassa quatro anos, sendo possível concluir, aparentemente, que o intuito do legislador ao editar a Lei não era a aplicação de penas privativas de liberdade.

Além da possibilidade de substituição supramencionada, a Lei no 9.605/98 também prevê, no art. 16, a suspensão condicional da pena, a qual poderá ser aplicada quando a condenação à pena privativa de liberdade for inferior a três anos. Nesse caso, não haverá execução da pena desde que o condenado se submeta às condições legais estabelecidas no art. 78 do Código Penal, como prestar serviços à comunidade (art. 46 do Código Penal) ou submeter-se à limitação de fim de semana (art. 48 do Código Penal). Também, se o dano for reparado, salvo impossibilidade de fazê-lo, e sendo as circunstâncias favoráveis ao condenado, as condições anteriores podem ser substituídas pelas seguintes, que podem ser aplicadas cumulativamente: proibição de frequentar determinados lugares, proibição de ausentar-se da comarca onde reside sem autorização judicial e comparecimento mensal, pessoal e obrigatório a juízo para informar e justificar suas atividades.

Ainda, por forçado art. 27 da Lei 9.605/98, os crimes ambientais que se enquadrem no conceito de infração de menor potencial ofensivo estarão sujeitos à aplicação dos institutos despenalizados (transação penal, composição dos danos e suspensão condicional do processo), previstos na Lei 9.099/9625.

Sobre a transação penal, Romeu Thomé ${ }^{26}$ explica, em sua obra, que o artigo 27 da Lei no 9.605/98 determina a prévia composição - ou reparação - do dano ambiental como pré-requisito

25 FIORILLO, Celso Antônio Pacheco; CONTE, Christiany Pegorari. op. cit., p. 105. 26 SILVA, Romeu Faria Thomé da. op. cit., p. 691-692. 
para o oferecimento do benefício nos crimes ambientais de menor potencial ofensivo, ou seja, aqueles em que a pena máxima seja inferior a dois anos, cumulada ou não com multa.

Contudo, referido instituto deve ser utilizado com cautela nos crimes ambientais, uma vez que o meio ambiente é um direito fundamental. Havendo aplicação desmedida da transação penal, é possível que ocorra uma inadequada e ineficaz compensação do dano ambiental por pena irrisória, o que pode servir de estímulo para novas práticas infracionais ambientais ${ }^{27}$.

O instituto dasuspensão condicional do processo, de igual maneira, pode ser proposto pelo Ministério Público pelo prazo de dois a quatro anos, período no qual o acusado deverá submeter-se às condições previstas no art. 89, da Lei 9.099/9528, de acordo com o art. 28 da Lei de Crimes Ambientais, desde que respeitados os seguintes requisitos: a) pena mínima cominada igual ou inferior a um ano; b) ausência de processos criminais em curso ou com condenação; c) ausência de condenação em crimes dolosos; d) culpabilidade, antecedentes, conduta social, personalidade do agente, motivos e circunstâncias compatíveis com a concessão do benefício, e; e) impossibilidade de aplicação da substituição prevista no art. 44 do Código Penal.

Evidente que tal suspensão pode ser revogada, no curso do prazo, se o beneficiário for processado por outro crime ou contravenção, se descumprir qualquer condição imposta ou não reparar o dano. Contudo, se expirado o prazo sem que a sursis processual seja revogada, o acusado terá extinta a punibilidade, dependendo apenas daelaboração de laudo técnico ${ }^{29}$.

27 FIORILlo, Celso Antônio Pacheco; CONTE, Christiany Pegorari. op. cit., p. 107 apud Recurso Criminal em Sentido Estrito n. 19990401006704-4/SC, 1 a Turma do TRF da 4⿳a Região, Rel. Juiz Vladimir Freitas. Recorrente; Ministério Público, Recorrido: Mauri Zimmermman, j. 27/04/99, DJU 09/06/99, p. 388.

28 FIORILlO, Celso Antônio Pacheco; CONTE, Christiany Pegorari. op. cit., p. 110-111.

29 Ibid., p. 112. 
Observa-se, portanto, da análise de todos esses institutos, que ao contrário do direito penal comum, que visa a prevenção coercitiva de lesões - por meio de sanção -, o direito penal ambiental, trazido pela Lei de Crimes Ambientais, demonstra caráter absolutamente reparatório, sendo chamado por alguns doutrinadores de "direito penal reparador"30.

Alex Santiago traz excelente reflexão em sua obra ao afirmar que a ciência penal vive momento de profunda crise, envolvendo eficiência (em razão dos elevados índices de violência, em decorrência dos escassos resultados), ética (demonstrada pelo caráter seletivo, desigual e orientado ideologicamente do sistema penal) e legitimação social (visto que os valores protegidos pelo direito penal nem sempre coincidem com as demandas do cidadão comum $)^{31}$.Em meio a tamanha crise, para além da proteção penal do meio ambiente como macro bem ambiental, encontram-se ainda os animais, que na maioria das vezes restam desprotegidos, sob a justificativa de haver "preocupações maiores" relacionadas à espécie humana.

Seja o momento propício ou não, o Direito deve encontrar meios para assegurar a proteção garantida pela Constituição Federal a esses seres. No entanto,verifica-se que os meios atualmente utilizados não parecem ser efetivos, uma vezque a principal lei penal ambiental brasileira prioriza a reparação do dano, mas parece deixar de observar que não há forma justa de reparação para a crueldade contra animais, principalmente porque, na maioria das vezes, os maus-tratos deixam sequelas ou ainda, de maneira mais gravosa, levam o animal a óbito. Assim, se considerado que o animal é um ser vivo que experimenta sensações comuns aos humanos (medo, dor, frio, fome, raiva etc.), o que permite sofri-

30 SANTIAGO, Alex Fernandes. op. cit., p. 89 apud LECEY, Eládio. Direito penal reparador. Revista de Direito Ambiental, vol. 45, Revista dos Tribunais, 2007, São Paulo.

31 Ibid., p. 92. 
mento, não existe reparação passível de ser aplicada diante da crueldade ou maus-tratos.

Alex Fernandes Santiago ${ }^{32}$ também esclarece que, embora dotadas de razão, as durascríticas tecidas pelos doutrinadores à forma de aplicação da Lei de Crimes Ambientais, principalmente no que tange a sua função reparadora, não observam que, desde a criação do diploma legal, a sanção nunca foi a finalidade principal, mas sim a reparação do dano. Tanto é assim que, conforme acima esmiuçado, a maioria dos tipos penais permite, pela pequena sanção que possui, a transação penal, sem processo, almejando a reparação do dano. E, somente se recusada a transação penal pelo autor do fato será proposta a ação penal, quando mais uma vez será oportunizada a possibilidade de afastar eventual condenação pela suspensão condicional do processo, aonde também será exigida a reparação do dano. Apenas se superados esses estágios sem a reparação é que haverá condenação penal, com imposição da pena cominada ao tipo penal correspondente.

Deste modo, quando se trata da proteção dos animais contra práticas cruéis, a aplicação da Lei seria mais adequada se tivesse como finalidade a prevenção do dano, por meio de sanções intimidadoras capazes de coibir abusos ou maus-tratos, caso contrário, abre-seespaço para o entendimento de que não há gravidade em maltratar animais pois, se reparado o dano, não há sanção, e se não há sanção, não há respeito à Lei penal. Como consequência, surge a sensação de impunidade, seja por parte dos defensores dos animais, seja por parte de quem pratica atos cruéis, uma vez que estes vivem com a certeza da ausência de punição. Em razão disso, questiona-se até que ponto a proteção da fauna é verdadeira, e a partir de onde essa pode começar a se demonstrar como sendo simbólica.

Assim, da análise das disposições mencionadas, verifica-se que a Lei de Crimes Ambientais possui um vasto rol de possibi-

32 SANTIAGO, Alex Fernandes. op. cit., p. 96. 
lidades para aplicação de penas alternativas, tendo em vista a intenção do legislador, quando da edição da norma, em privilegiar a reparação do dano, e não a sua prevenção. Porém, referido tratamento demonstra-se extremamente prejudicial à tutela penal dos animais, uma vez que, em se tratando de seres vivos, a reparação do dano pode não ser possível ou suficiente.

\subsection{O CRIME DE MAUS-TRATOS: O ART. 32 DA LEI DE CRIMES} AMBIENTAIS

Conforme já abordado, a Lei de Crimes Ambientais foi criada para regulamentar a disposição do art. 225, §3ํ da Constituição Federal, prevendo uma série de sanções penais e administrativas para aqueles que praticarem atos lesivos ao meio ambiente.

Como complemento à previsão do art. $225, \S 1^{\circ}$, inciso VII da CF, que trata da proteção faunística e proibição de submissão dos animais à crueldade, a Lei de Crimes Ambientais dedicou um capítulo inteiro aos crimes contra a fauna (do art. 29 ao 37), o qual busca assegurar, nos diferentes tipos penais, a proteção jurídico-penal de todos os animais, sejam eles domésticos, domesticados, silvestres, exóticos ou nativos.

Dentre os tipos penais que tutelam a fauna, destaca-se o tipo penal do art. 32 da Lei de Crimes Ambientais, o único passível de aplicação contra aqueles que praticarem crimes contra animais domésticos e domesticados, uma vez que todas os demais tipos penais que tutelam a fauna preocupam-se em tipificar condutas envolvendo caça, pesca, tráfico ou lesão a animais nativos, silvestres e exóticos, visto que estes possuem função ecológica relevante ao meio ambiente e, consequentemente, à preservação da sadia qualidade de vida humana.

Referido artigo, traz a seguinte redação, litteris:

Art. 32. Praticar ato de abuso, maus-tratos, ferir ou mutilar animais silvestres, domésticos ou domesticados, nativos ou exóticos:

Pena - detenção, de 3 (três meses a 1 (um) ano, e multa. 
$\S 1^{0}$ Incorre nas mesmas penas quem realiza experiência dolorosa ou cruel em animal vivo, ainda que para fins didáticos ou científicos, quando existirem recursos alternativos.

$\S 2^{\circ}$ A pena é aumentada de um sexto a um terço, se ocorre morte do animal.

Renato Marcão ${ }^{33}$ afirma que o desejo do legislador, ao elaborar a redação do art. 32 , foi no sentido de abranger todo e qualquer tipo de animal; por esse motivo preocupou-se em elencá-los como silvestre, doméstico, domesticado, nativo ou exótico.

No entanto, basta uma breveanálise do dispositivo legal para que se questione sua efetividade, não apenas com relação à proteção dos animais, a qual deriva diretamente do mandamento constitucional do art. 225, §1ํㅡ, VII, mas também da aplicação da punição imposta pela prática do crime. Isso porque, sendo imposta pena de detenção, pelo período de três meses a um ano, podem ser aplicadas diversas substituições (por penas restritivas de direitos, oferecimento de transação penal pelo Ministério Público ou, ainda, suspensão condicional do processo), o que pode não trazer, de forma satisfatória, consequências reflexivas para quem já cometeu o crime, ou preventivas (socioeducativas) em relação à ocorrência de novos delitos.

Desta maneira, tem-se que a Lei de Crimes Ambientais, quando trata do crime de maus-tratos, não respeita o Princípio da Proporcionalidade, uma vez que as sanções não estão de acordo com a gravidade das condutas praticadas. Como consequência, todo o processo, que envolve uma correta aplicabilidade do Direito, resta comprometido, resultando, muitas vezes, em decisões judiciais notadamente equivocadas ${ }^{34}$.

33 MARCÃO, Renato. Crimes ambientais (Anotações e interpretação jurisprudencial da parte criminal da Lei n. 9.605, de 12-2-1998). 2a ed. rev., atual. e de acordo com o Novo Código Florestal (Lei n. 12.651/2012). São Paulo: Ed. Saraiva, 2013, p. 83.

34 TOLEDO, Maria Izabel Vasco de. op. cit.,loc.cit. 
De outra forma, como alternativa ao baixo caráter punitivo da Lei, poderia ser dada maior relevância à pena de multa, visando que fosse encarada comoverdadeiro ônus ao delinquente, passível de desencorajá-loou servir de exemplo aos demais ${ }^{35}$. Porém, o que se verifica na prática, é a não-ocorrência de nenhuma dessas penalidades, pois na maioria dos casos há aplicação de penas substitutivas.

João Alves Teixeira Neto, em obra dedicada exclusivamente à tutela penal dos animais, afirma que o principal problema relacionado à proteção desses seres contra a crueldade é que o tipo penal não está positivado nem no Código Penal, e nem uma específica Lei de Proteção dos Animais, mas sim na Lei de Crimes Ambientais. Essa inadequada alocação do tipo penal, por si só, já traria prejuízos à tutela penal dos animais ${ }^{36}$. Concorda-se com o referido autor neste particular, bem como com as críticas por ele tecidas ao fato de o resultado morte, por meio da inclusão do verbo "matar", não estar previsto no caput do artigo 32 da Lei de Crimes Ambientais ${ }^{37}$.

Imprescindível salientar, entretanto, que posicionamentos como o de João Alves Teixeira Neto são minoritários em matéria penal ambiental, a exemplo de Luiz Regis Prado, renomadopenalista brasileiro, que entende que a Lei de Crimes Ambientais é altamente criminalizadora, visto que define como crime vários comportamentos que não deveriam passar de infrações administrativas ou de contravenções penais, citando, dentre os seus exemplos, o artigo 32 da Lei de Crimes Ambientais ${ }^{38}$.

Do mesmo modo, há outras críticas ao art. 32 pela doutrina brasileira. Carlos Ernani Constantino, por exemplo, embora tenha certa razão quanto à desproporcionalidade das penas, trata de

\footnotetext{
35 Ibid., p. 8.

36 TEIXEIRA NETO, João Alves. Tutela penal dos animais: uma compreensão onto-antropológica. Porto Alegre: Ed. Livraria do Advogado, 2017, p. 198-199.

37 Ibid., p. 200.

38 PRADO, Luiz Regis. Direito penal do ambiente. op. cit., p. 164.
} 
maneira quase pejorativa a nomenclatura dada ao tipo penal, uma vez que idêntica àquela prevista no art. 136 do Código Penal, que trata de maus-tratos contra seres humanos ${ }^{39}$. Discorda-se veementemente do referido autor neste particular, pois se é certo que os seres humanos merecem proteção penal contra maustratos, não é menos certo que os animais, enquanto seres vivos, também merecem uma tutela penal adequada, a fim de impedir que referidas práticas continuem sendo realizadas.

Assim, é possível verificar que mesmo significativa parcela da doutrina não compreende a proteção animal como um dever penalmente relevante, fato que, combinado com a característica de ultimaratiodo Direito Penal, pode esclarecer, de certa forma, por que as penas aplicáveis nos crimes contra a fauna, notadamente aquela cominada ao crime de maus-tratos a animais, são tão baixas na Lei de Crimes Ambientais.

\section{A PROTEÇÃO SIMBÓLICA DO CRIME DE MAUS-TRATOS AOS ANIMAIS}

Como reiteradamente mencionado, a Constituição Federal de 1988 preocupou-se em prever o dever de proteção aos animais e criou mecanismos para garantir que esse dever fosse cumprido, por meio da tutela penal. Porém, a Lei Crimes Ambientais parece não ser a mais adequada à tutela penal dos animais, considerando que a fixação de penas excessivamente brandas pode não atingir o resultado preventivo esperado pelo direito penal, o qual, digase de passagem,não é a função principal assumida pelo direito penal ambiental, como já destacado.

Nas palavras de Alex Fernandes Santiago ${ }^{40}$, cabe ao Direito a difícil decisão de tornar mais rigorosa a legislação penal, como

39 CONSTANTINO, Carlos Ernani. Delitos ecológicos:a lei comentada artigo por artigo. Aspectos penais e processuais penais. 2ª ed. São Paulo: Ed. Atlas, 2002, p. 122.

40 SANTIAG0, Alex Fernandes. op. cit., p. 25. 
forma de tentar aplicar com efetividade o Direito Penal Ambiental, o qual hoje é tido como simbólico. Caso contrário, deve ser retirada a matéria ambiental do campo da proteção penal, pois inútil.

Como efeito, pode-se dizer que a Lei de Crimes Ambientais protege os animais de forma simbólica, principalmente os domésticos, tendo em vista que não se vislumbra real repressão contra a prática do crime de maus-tratos, uma vez que a pena é extremamente baixa e, como já tratado, possibilita diversas substituições que visam a reparação do dano ambiental.

Contudo, essa proteção simbólica não está unicamente relacionada à finalidade da Lei, considerando que há, também, uma série de causas interligadas que fragilizam a aplicação da pena prevista no dispositivo, conforme será abordado a partir de agora.

\subsection{NORMA PENAL EM BRANCO E A LEI DE CRIMES AMBIENTAIS}

Para que a aplicação de uma lei possa ocorrer de forma efetiva, um dos primeiros pontos que deve ser observado é a completude da previsão. Sobre esse assunto, alguns autores fazem duras críticas à Lei de Crimes de Ambientais, justamente pela apresentação de excessivas lacunas.

Sobre o assunto, Alex Fernandes Santiago acredita que a redação da Lei 9.605/98 possui tantas normas penais em branco em razão de um conflito existente entre parlamentares que se dividiam, à época da criação da Lei, entre o crescimento econômico e a proteção do meio ambiente. Por esse motivo, o conflito teria se reproduzido em normas penais em branco, que quando mal manejadas podem conduzir a um direito penal simbólico ${ }^{41}$.

Já para Ivan Luiz da Silva ${ }^{42}$, a justificativa está na complexidade de individualizar e tipificar condutas proibidas em matéria ambiental, uma vez que esta traz conceitos amplos. Apesar disso, entende que a descrição incompleta acarreta na complementação

41 SANTIAGO, Alex Fernandes. op. cit., p. 45.

42 SILVA, Ivan Luiz da. op. cit., p. 75. 
realizada por meio de um juízo valorativo do julgador, o que pode ser prejudicial à penalização. Assim, a utilização de normas penais em branco enfraqueceria a tutela penal do meio ambiente, uma vez que diminui a determinabilidade e a certeza do tipo, fatores imprescindíveis à ideal aplicação do Direito Penal.

Para preencher essas lacunas, são utilizadas inúmeras normas penais e administrativas, além de outros regulamentos federais, estaduais e municipais e resoluções internas de órgãos encarregados da gestão ambiental (Ibama, Conama, etc. ${ }^{43}$.

No mesmo sentido, Paulo José da Costa Jr. leciona que, havendo preceitos lacunosos, a busca pela complementação deve ser realizada em outros dispositivos legais, inclusive de natureza extrapenal $^{44}$, o que pode, como regra geral, ser bastante prejudicial à aplicação da pena, uma vez que o Direito Penal deve definir com completude e autonomia os componentes de suas normas, sem apresentar enunciados vagos ${ }^{45}$.

Romeu Thomé ${ }^{46}$, do mesmo modo, ensina que a norma penal em branco pode utilizar-se de complementação por: disposição prevista na mesma lei, disposição prevista em outra lei, ou ainda, disposição emanada de outra lei, ou seja, de um ato administrativo. Como exemplo, cita o artigo 29 , § 4ํㅡ, I, uma vez que este dispositivo utiliza a expressão espécies ameaçadas de extinção, mas não as define, sendo necessário recorrer às listas oficiais do IBAMA.

Especificamente quanto ao art. 32 da Lei 9.605/98, não existe na legislação vigente conceito para os termos maus-tratos e abuso de animais, razão pela qual a doutrina e o judiciário vêm

43 FIORILlO, Celso Antônio Pacheco; CONTE, Christiany Pegorari. op cit, p. 15.

44 MILARÉ, Édis; COSTA JR., Paulo José da Costa; COSTA, Fernando José da. Direito penal ambiental. 2 $2^{\text {a }}$ ed. rev., atual. e ampl. São Paulo: Ed. Revista dos Tribunais, 2013, p. 51 apud FERREIRA, Ivete Senise. 0 direito penal ambiental. Revista do Advogado - ASSP. São Paulo: ASSP, 1991, p. 87.

45 Ibid., p. 51 apud PRADO, Luiz Regis. Direito penal ambiental. São Paulo: Ed. Revista dos Tribunais, 1992, p. 42.

46 SILVA, Romeu Faria Thomé da. Manual de direito ambiental. op. cit., p. 674. 
preenchendo essa "lacuna" por meio de noções gerais sobre o assunto, e sempre, mediante análise do caso concreto.

É notório que os doutrinadores buscam conceituar as práticas da melhor forma possível, no entanto, a ausência de conceituação legal abre espaço para interpretações das mais diversas, podendo a lei ser aplicada, em cada caso, de acordo com o conceito de maus-tratos compreendido como mais adequado pelo julgador, situação que pode comprometer, e muito, a efetividade da norma.

Cabe mencionar que alguns doutrinadores ainda baseiam-se, para formular os conceitos de maus-tratos e abuso de animais, na redação do Decreto 24.645, de 10 de julho de $1934^{47}$, o qual elencava, em seu art. $3^{3}$, todas as condutas que configuravam maustratos. Há, porém, extensa discussão relacionada a sua vigência.

Enquanto Renato Marcão ${ }^{48}$ afirma que a norma foi revogada pelo Decreto no 11 , de 1991, João Marcos Adede Y Castro ${ }^{49}$ defende que essa permanece vigente, tendo em vista possuir condição equiparada à lei, o que impossibilitaria sua revogação por decreto editado em período de plena atividade legislativa.

Ocorre que, pela vigência ou não do Decreto, o simples fato de haver divergência sobre sua aplicação já é prejudicial à efetividade da Lei 9.605/98, uma vez que, na ausência de disposição cristalina, o julgador pode utilizar-se de suas convicções pessoais para definir quais práticas podem ser consideradas como abuso ou maus-tratos.

Assim, conclui-se que, quando analisado o enquadramento de ato praticado no crime previsto no art. 32 da Lei 9.605/98, a ausência de conceituação para os termos supramencionados cria entravespara a efetividade da norma, sendo esse um dos fatores que acarretam na proteção simbólica dos animais.

47 MARCÃO, Renato. op. cit., p. 85.

48 Ibid.,loc. cit.

49 CASTRO, João Marcos Adede y. op. cit., p. 71 apud MARTINS, Renata de Freitas. Direitos dos animais. In: http://www.suigeneris.pro.br. 


\subsection{O STATUS JURÍDICO DO ANIMAL NO DIREITO CIVIL BRASILEIRO}

Como visto, é incontestável que a forma de edição do art. 32 da Lei de Crimes Ambientais trouxe uma série de problemas à garantia da punição pela prática do crime, seja pela imposição de penas excessivamente brandas, seja pela flexibilidade da conceituação do termo maus-tratos, em decorrência das lacunas apresentadas pela legislação. Porém, a dificuldade em garantir a adequada tutela penal dos animais pode, do mesmo modo, estar interligada a previsões constantes em outros ramos do Direito.

Isso porque, o Direito Civil brasileiro ${ }^{50}$ não entende os

50 Além do art. 82, o Código Civil de 2002 traz uma série de dispositivos que demonstram claramente o enquadramento do animal como res e que regulam a sua propriedade, especificando direitos e obrigações dos proprietários com relação aos animais e a terceiros, tais como:

Art. 936. 0 dono, ou detentor, do animal ressarcirá o dano por este causado, se não provar culpa da vítima ou força maior;

Art. 964.Tem privilegio especial:

(...) IX. Sobre os produtos do abate, o credor por animais;

Art. 1.297. O proprietário tem direito a cercar, murar, valar ou tapar de qualquer modo o seu prédio, urbano ou rural, e pode constranger o seu confinante a proceder com ele à demarcação entre os dois prédios, a aviventar rumos apagados e a renovar marcos destruídos ou arruinados, repartindo-se proporcionalmente entre os interessados as respectivas despesas.

(...) $\S 3^{\circ}$ A construção de tapumes especiais para impedir a passagem de animais de pequeno porte, ou para outro fim, pode ser exigida de quem provocou a necessidade deles, pelo proprietário, que não está obrigado a concorrer para as despesas.

Art. 1.313. 0 proprietário ou ocupante do imóvel é obrigado a tolerar que o vizinho entre no prédio, mediante prévio aviso, para:

(...) II - apoderar-se de coisas suas, inclusive animais que aí se encontrem casualmente;

Art. 1.397. As crias dos animais pertencem ao usufrutuário, deduzidas quantas bastem para inteirar as cabeças de gado existentes ao começar o usufruto;

Art. 1.442. Podem ser objeto de penhor:

(...) V - animais do serviço ordinário de estabelecimento agrícola;

Art. 1.444. Podem ser objeto de penhor os animais que integram a atividade pastoril, agrícola ou de lacticínios; Art. 1.445. 0 devedor não poderá alienar os animais empenhados sem prévio consentimento, por escrito, do credor. 
animais como sujeitos de direitos, mas sim, como coisas passíveis de apropriação, tal como prevê o artigo 82 do Código Civil de 2002: são móveis os bens suscetíveis de movimento próprio, ou de remoção por força alheia, sem alteração da substância ou da destinação econômico-social.

Como consequência desse entendimento, tem-se uma cultura de livre disposição de atos dos proprietários sobre os seus bens semoventes, e em razão disso, a própria avaliação do dolo nos casos de maus-tratos acaba sendo dificultada, tendo em vista a crença popular de que o dono do animal pode fazer com ele o que quiser ${ }^{51}$.

Para romper com esse paradigma, alguns doutrinadores atuais dos cenários nacional e internacional defendem um novo campo de estudo da ciência jurídica, denominado "Direito dos Animais". Nesse novo cenário, enquanto alguns autores entendem que o problema está na não-consideração do animal como sujeito de direitos, outros afirmam que tanto a Constituição Federal quanto o Código Civil já não tratam os animais como os outros bens móveis.

Nesse sentido, João Marcos Adede Y Castro entende que os animais podem até ter valor econômico, mas não são coisas ou bens, nos termos do Direito Civil, para que os proprietários utili-

Parágrafo único. Quando o devedor pretende alienar o gado empenhado ou, por negligência, ameace prejudicar o credor, poderá este requerer se depositem os animais sob a guarda de terceiro, ou exigir que se lhe pague a dívida de imediato;

Art. 1.446. Os animais da mesma espécie, comprados para substituir os mortos, ficam sub-rogados no penhor. Parágrafo único. Presume-se a substituição prevista neste artigo, mas não terá eficácia contra terceiros, se não constar de menção adicional ao respectivo contrato, a qual deverá ser averbada;

Art. 1.447. Podem ser objeto de penhor máquinas, aparelhos, materiais, instrumentos, instalados e em funcionamento, com os acessórios ou sem eles; animais, utilizados na indústria; sal e bens destinados à exploração das salinas; produtos de suinocultura, animais destinados à industrialização de carnes e derivados; matérias-primas e produtos industrializados.

51 MILARÉ, Édis; COSTA JR., Paulo José da Costa; COSTA, Fernando José da. op. cit., p. 92 apud FREITAS, Vladimir Passos de; FREITAS, Gilberto Passos de.

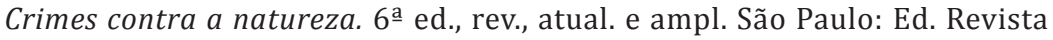
dos Tribunais, 2000, p. 94. 
zem-nos como bem entenderem, visto que a ideia de propriedade privada já não confere ao proprietário poderes absolutos, pois sofrem, atualmente, inúmeras restrições de ordem legal e social. A partir desse raciocínio, o dono de um animal não seria nada além de um simples detentor, guardião e responsável pela manutenção desses seres, não podendo abandoná-los ou maltratá-los ${ }^{52}$.

$\mathrm{Na}$ mesma obra, o autor defende que, de certa forma, em razão da previsão constitucional de proteção da vida animal e da possibilidade de defesa dos animais judicialmente, estes já podem ser considerados como sujeitos de direito ${ }^{53}$. Tal fenômeno ocorreria porque embora a dogmática jurídica indique que apenas o homem pode ser sujeito de direitos, esta lógica se inverteria no Direito Ambiental, pois este aceita a ideia de que o ser humano é mero representante dos animais, em juízo, assim como sucede com as pessoas jurídicas. "Assim, o direito dos animais, em termos de processo, administrativo ou judicial, é beneficiado pelas mesmas garantias asseguradas aos homens ${ }^{54 "}$.

João Marcos Adedey Castro refere ainda, que no âmbito do Direito Civil, o art. $1.228, \S 1^{\circ}$ do CC, condiciona a propriedade da fauna à preservação prevista em lei especial, o que justificaria, caso não observadas as medidas de proteção e os interesses sociais, que houvesse a desapropriação dos animais, por não desempenharem sua função social ${ }^{55}$, uma vez que a Constituição Federal refere-se a bens, lato sensu ${ }^{56}$.

Referido entendimento, entretanto, é inovador e não condiz com os ensinamentos da maioria esmagadora dos autores de Direito Civil, os quais classificam os animais, de maneira expressa, como propriedade dos seres humanos.

\footnotetext{
52 CASTRO, João Marcos Adede y. op. cit., p. 46.

53 Ibid., p. 45.

54 Ibid., loc. cit.apud SILVA, Olmiro Ferreira da. Direito Ambiental e Ecologia: aspectos filosóficos contemporâneos. Barueri: Manole, 2003, p. 11

55 CASTRO, João Marcos Adede y. op. cit., p. 63.

56 Ibid., p. 64.
} 
Já em matéria penal, Carlos Ernani Constantino ${ }^{57}$, por exemplo, quando trata do art. 32 em sua obra, refere que o abuso em questão refere-se ao uso excessivo, o que reforça a ideia de que o animal é tratado como res.

$\mathrm{Na}$ defesa de uma reclassificação dos animais dentro do Direito Civil, alguns doutrinadores analisam a questão por outro viés, utilizando-se de preceitos filosóficos para expor suas correntes de pensamento, mas todas no sentido da existência de um dever do ser humano de respeitar as demais espécies enquanto seres vivos, assim como mencionado por João Marcos Adede Y Castro, em sua obra.

Há ainda, autores que defendem a desnecessidade de vinculação entre Direito Civil e Direito Penal para que se garanta uma adequada tutela penal dos animais. Nessa linha de pensamento, destaca-se a posição de João Alves Teixeira Neto, quando afirma que os animais podem, sim, ser titulares de um bem jurídico-penal - o que implicaria o seu reconhecimento como vítimas do crime sem que, para isso, sejam, necessariamente, considerados sujeitos de direitos, em virtude dos inúmeros problemas que poderiam surgir com essa consideração, a começar pela indústria alimentícia ${ }^{58}$.

Sobre o aspecto legal, o crescente interesse da sociedade por animais domésticos fez surgir não apenas maior comoção, mas também maior percepção de que os animais são dotados de vida e sentimentos. Como reflexo disso, no ano de 2015 foi aprovado pela Constituição de Comissão e Justiça (CCJ), o Projeto de Lei no $351 / 2015^{59}$, que pretende inserir, no Código Civil, previsão ex-

57 CONSTANTINO, Carlos Ernani. op. cit., p. 122.

58 TEIXEIRA NETO, João Alves.Op. cit., p. 39.

59 O Projeto de Lei aguarda, desde então, a votação pela Câmara dos Deputados, conforme andamento constante em:<https://www25.senado.leg.br/web/ atividade/materias/-/materia/121697>. Acesso em: 21 nov.2017.

Íntegra do projeto: BRASIL. Projeto de Lei do Senado $n^{\circ}$ 351, de 2015. Disponível em: <http://legis.senado.leg.br/sdleg-getter/documento?dm=3530675\&disposition=inline>. Acesso em: 02 nov.2017. Ainda sobre o assunto, notícia que comemora a aprovação do projeto, veiculada no sítio do Partido Social 
pressa de que os animais não são coisas. No entanto, para efeitos jurídicos, se aprovado definitivamente, o animal passará apenas a ser uma coisa sui generis, não havendo mudança significativa em seu status jurídico. Por outro lado, admite-se que já é um grande passo na busca por direitos aos animais.

De qualquer sorte, mesmo com o surgimento - em fase inicial - de uma mudança na perspectiva sobre a vida animal, enquanto esses forem considerados como propriedade, esse tratamento pode trazer prejuízos às previsões constantes na esfera penal, uma vez que o bem jurídico a ser tutelado pelo Direito Penal deve possuir relevância social, e isso não pode ser atingido de maneira satisfatória se mantido o atual entendimento civilista.

3.3 A PERSPECTIVA ANTROPOCENNTRICA DO CRIME DE MAUS-TRATOS: A SOCIEDADE COMO SUJEITO PASSIVO DO DELITO

Osurgimento do Direito, de um modo geral, está intimamente ligado ao antropocentrismo, tendo em vista que as ciências jurídicas surgiram com o intuito de regular as condutas e as relações humanas, o que significa dizer, inicialmente, que as leis são criadas por seres humanos para seres humanos.

Deste modo, assim como nos demais ramos do Direito, a visão antropocêntrica foi adotada pelo direito ambiental brasileiro, na medida em que a proteção do ambiente tutela interesse humano, pois se entende o homem como ser dependente do meio ambiente e de tudo que o compõe, e a natureza como algo dotado de um valor instrumental ${ }^{60}$.Tanto é assim, que o direito

Democrata Brasileiro (PSDB): ASSESSORIA DE IMPRENSA. Aprovado projeto de Anastasia para proteção dos animais. Disponível em: <http://www.psdb. org.br/acompanhe/aprovado-projeto-de-anastasia-para-protecao-dos-animais/> Acesso realizado em 02 nov.2017.

60 AMADO, Frederico Augusto Di Trindade. Direito ambiental esquematizado. $7^{\mathrm{a}}$ ed. rev. e atual. Rio de Janeiro: Ed. Forense. São Paulo, Ed. Método, 2016, p. 5 apud ALMEIDA, António. Como se posicionam os professores perante manifestações culturais com impacto na natureza. Resultados de uma investigação. Revista Electrónica de Enseñanza de las Ciencias, vol. 8, nํㅡ. 2. Lisboa, 2009, p. 649. Disponível em: <http://reec.uvigo.es/volumenes/voumen8/ ART15_Vol8_N2.pdf.>. Acesso em: 24 nov. 2009. 
ao meio ambiente ecologicamente equilibrado integra o rol de direitos humanos fundamentais, indispensável à sobrevivência da espécie humana.

A partir desse entendimento, é possível compreender que o meio ambiente é protegido com a finalidade de preservar a vida humana, não havendo, portanto, proteção das vidas não-humanas em razão de sua condição de seres vivos.

Para Romeu Thomé61, a Constituição Federal de 1988, assim como a grande maioria das normas ambientais nacionais e internacionais, adota o antropocentrismo protecionista, o qual crê que o ambiente não se restringe à mera concepção econômica ou àsujeição direta a interesses humanos. A proteção aplicada, entretanto, estaria longe daquela defendida pela corrente ecocêntrica, que defende a não instrumentalização do meio ambiente e a proteção de cada ser vivo ${ }^{62}$.

Segundo Romeu Thomé, no Brasil, a corrente ecocêntricaéde difícil aplicação, em decorrência da necessidade de utilização dos recursos naturais. Porém, entende que a tendência é que haja uma ampliação da proteção dos recursos ambientais, já sendo possível, inclusive, identificar traços biocêntricos e ecocêntricos em normas de proteção ambiental vigentes ${ }^{63}$.

Frederico Amado compartilha desse mesmo entendimento. O autor acredita que a Constituição Federal de 1988 adotou o antropocentrismo, mitigado por doses de biocentrismo e de ecocentrismo, uma vez que o caput do art. 225 possui nítida carga antropocêntrica, pois instituiu o direito fundamental de todos ao meio ambiente ecologicamente equilibrado ${ }^{64}$, enquanto que os

61 SILVA, Romeu Faria Thomé da. op. cit., p. 58-59 apud LEITE, José Rubens Morato. Dano Ambiental: do individual ao coletivo extrapatrimonial. São Paulo: Ed. Revisa dos Tribunais, 2002, p. 140-141.

62 AMADO, Frederico Augusto Di Trindade. op. cit., p. 5 apud ALMEIDA, António. op. cit., loc. cit.

63 SILVA, Romeu Faria Thomé da. op. cit., p. 59.

64 AMADO, Frederico Augusto Di Trindade. op. cit., p. 10. 
incisos que tratam da proteção da fauna e da flora são inspirados primordialmente nas linhas ecocêntricas e biocêntricas ${ }^{65}$, tendo em vista que proíbem a submissão dos animais à crueldade, independentemente de regulamentação, pois se trata de norma constitucional de eficácia plena ${ }^{66}$.

A defesa dos direitos dos animais é inspirada no biocentrismo, visto que esse novo campo de estudoé contrário à utilização dos animais como instrumentos do homem ou sua propriedade, e chega a apontá-loscomo sujeitos de alguns direitos, no que tange aos animais sencientes e autoconscientes. O Brasil, porém, entende que os animais são objetos de direito, como já abordado no item anterior, mas reconhece um regime jurídico especial, por estarem vivos, sendo vedados atos cruéis contra esses seres ${ }^{67}$.

Frederico Amado ${ }^{68}$ ainda menciona que a previsão constitucional constante no art. 225, $§ 1^{\circ}$, inciso VII da Constituição inovou ao tutelar todos os animais, inclusive os domésticos, uma vez que esses podem ser de propriedade privada. Acredita, contudo, que o entendimento jurídico civilista deve ser adaptado à condição desses enquanto seres vivos. Apesar disso, finaliza afirmando que o sujeito passivo dos crimes ambientais sempre é a coletividade $^{69}$, considerando a corrente antropocêntrica seguida pelo Direito brasileiro.

Seguindo esse raciocínio, com relação à tutela penal do meio ambiente, a legitimidadeadvém do grau de importância desse bem para a existência dos seres humanos, que necessitam de um meio ambiente sadio e ecologicamente equilibrado para sobreviver e desenvolver-se ${ }^{70}$.Por esse motivo, no que tange à fauna, a doutrina brasileira majoritária compreende a sociedade em geral

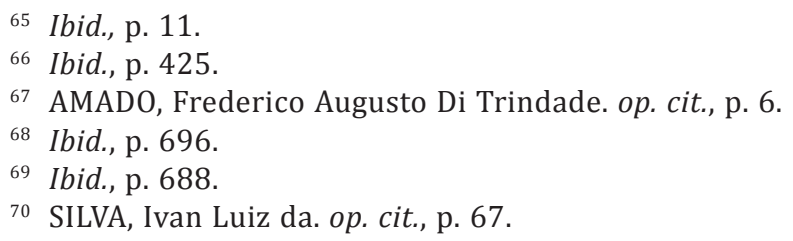


(ou coletividade) como sujeito passivo do delito, o que significa dizer que os animais são apenas objetos materiais da conduta ${ }^{71}$.

Contudo, verifica-se certa inconsistênciaentre essa visão e o objetivo das previsões do art. 225, §1ํㅡㄹ inciso VII, da CF/88, edo art. 32 da Lei de Crimes Ambientais. Isso porque, de acordo com os preceitos antropocêntricos, a fauna deve ser protegida por ser parte integrante do meio ambiente e possuir importante função ecológica. No entanto, referidos artigos visam, na verdade, proteger os animais contra práticas cruéis, ou seja, contra sofrimento ou condutas que violem sua vida ou sua integridade física. Desse modo, não parece que a proteção do dispositivo possua o intuito de evitar desequilíbrios ecológicos e preservar a espécie humana, mas sim proteger os animais, enquanto seres individuais, contra a crueldade, revelando as doses de bio e ecocentrismo mencionadas por Frederico Amado.

A partir do momento em que se constataque um animal teve sua vida ou integridade física violada, é extremamente incoerente considerar que a sociedade foi a vítima do delito, principalmente quando não há sequer impactos ambientais decorrentes da conduta, o que ocorre quando animais domésticos são abusados ou maltratados.

ÉdisMilaré ${ }^{72}$ demonstra claramente em sua obra que o entendimento doutrinário é contraditório quando se trata desse assunto, uma vez que o autor afirma que a sociedade é o sujeito passivo do delito e ao mesmo tempo aduz que a objetividade jurídica da previsão é evitar o sofrimento dos animais.

Já Luiz Regis Prado chega a afirmar, em sua obra, que no crime previsto no art. 32, o bem tutelado é o legítimo sentimento de humanidade (piedade, compaixão ou benevolência), o qual

71 MILARÉ, Édis; COSTA JR., Paulo José da Costa; COSTA, Fernando José da. op. cit., p. 90.

72 MILARÉ, Édis; COSTA JR., Paulo José da Costa; COSTA, Fernando José da. op. cit., p. 93. 
deve ser portado pela sociedade diante de atos dessa natureza, considerando que é dever de todo ser humano respeitar todos os demais seres vivos ${ }^{73}$. Contudo, entender um sentimento como bem a ser tutelado é, no mínimo, arriscado, tendo em vista que a benevolência não é inerente ao ser humano, principalmente se observada a prática de crimes contra outros seres humanos sem nenhuma demonstração de arrependimentos.

Sobre a questão, Édis Milaré também afirma que a fauna é protegida para dar vazão ao mandamento constitucional consistente em garantir à presente e às futuras gerações um meio ambiente equilibrado, de modo que o sujeito de direito seria o ser humano e os animais seres que possuem a integridade tutelada por via reflexa ${ }^{74}$.

Deste modo, a visão antropocêntrica do direito brasileiro também parece ser uma das causas que dificultam a ideal aplicação do art. 32 da Lei de Crimes Ambientais, fazendo a legislação seja aplicada de forma contraditória, na contramão da previsão constitucional de vedação à crueldade, visto que considera como vítima do crime a sociedade ao invés de observar quem realmente sofre a lesão tipificada e é alvo da prática cruel.

\subsection{O ANIMAL COMO SERMERECEDOR DE ADEQUADA TUTELA PENAL}

Ao verificar que o legislador constitucional preocupou-se em expressar, na Carta Magna, a necessidade de proteção da fauna e a vedação de práticas cruéis contra animais, é impossível não pensar que foi considerada, mesmo que de forma singela, a dignidade destes enquanto seres vivos. Para além disso, quando se fala em crueldade, automaticamente se pensa em sofrimento, o que está relacionado diretamente à capacidade de sentir.

73 PRAD0, Luiz Regis. op. cit., p. 199.

74 MILARÉ, Édis; COSTA JR., Paulo José da Costa; COSTA, Fernando José da. op. cit., p. 81. 
Mas se os animais são seres vivos capazes de sentir, de maneira semelhante aos seres humanos, por que são considerados propriedade e não como sujeitos de direito? Por que, também, não podem ser considerados como vítimas de um crime em que, eles são, de fato,vítimas? Referidas perguntas definitivamente não são fáceis de serem respondidas, mas possíveis respostas já podem ter sido mencionadas ao longo deste estudo, tais como a visão antropocêntrica do Direito ou mesmo a cultura humana de apropriar-se de tudo que está "a sua disposição", em forma de bens, ou que gere retorno financeiro.

Independentemente da resposta, pode-se observar que a grande maioria dos doutrinadores, mesmo que por razões diferentes, tem algo em comum, desde os seguidores de correntes antropocêntricas até aqueles que já defendem os animais como sujeitos de direitos: todos defendem a necessidade de proteger os animais, de uma forma ou de outra.No entanto, conforme pôde ser observado nos tópicos anteriores, nem todos concordam que o Direito Penal seja a via mais adequada para tutelá-los.

Com o crescimento de adeptos às teorias como a de Peter Singer ${ }^{75}$ - que não se preocupa tanto comos direitos positivados, mas sim com a senciência animal ${ }^{76}$, propondo que se estenda

75 Cf. SINGER, Peter. Libertação Animal. Tradução Marly Winckler e Marcelo Brandão Cipolla. São Paulo: Martin Fontes, 2010.

76 Carlos Michelon Naconecy, em sua obra Ética \& animais, traz o conceito de senciência animal: (i) Dizer que um animal é senciente significa dizer que esse animal (a) tem a capacidade de sentir, e (b) que ele se importa com o que sente. "Importar-se com" implica a capacidade de experimentar satisfação ou frustração (subjetiva). (ii) Para a Ética Animal em especial, dizer que um animal é senciente equivale a dizer que o animal é (a) capaz de sentir dor e (b) desejar que ela acabe. (iii) Isso significa, mais especificamente, que o animal percebe ou está consciente de como se sente, onde está, com quem está, e como é tratado. Ou seja, a) tem sensações como dor, fome e frio; b) tem emoções relacionadas com aquilo que sente, como medo, estresse e frustração; c) percebe o que está acontecendo com ele; d) é capaz de apreender com a experiência; e) é capaz de reconhecer seu ambiente; f) tem consciência de suas relações com outros animais e com os seres humanos; g) é capaz de distinguir e escolher entre objetos, outros animais e situações 
aos animais uma igual consideração de interesses - e a de Tom $\operatorname{Regan}^{77}$ - que elevou esses sentimentos ao campo dos direitos morais, afirmando serem os animais "sujeitos de uma vida" -, parece cada vez mais próxima a ideia de que "os animais, como seres semelhantes aos humanos, possuem o direito moral, aquele direito que antecede a qualquer ordenamento jurídico, ou seja, a qualquer direito positivo ${ }^{78}$." E justamente por esse motivo, é que merecem tanto quanto os seres humanos que sua vida e sua integridade física sejam tuteladas pelodireito penal, enquanto ramo mais gravoso do Direito, principalmente quando são abusados por aqueles a quem cabia a sua proteção, como no caso dos animais domésticos.

A senciênciaé uma característica de muitos animais não humanos que os torna semelhantes aos animais humanos. Em razão dessa semelhança, verifica-se, mesmo que a passos lentos, uma gradual mudança de paradigma no próprio Direito Civil, aquele que classifica o animal como res. Isso porque os

diferentes, mostrando que entende o que está acontecendo em seu meio; h) avalia aquilo que é visto e sentido, e elabora estratégias concretas para lidar com isso. (iv) Apesar de frequentemente serem tomadas como sinônimos, a senciência pode ser diferenciada da sensibilidade. Organismos unicelulares, vegetais, filmes fotográficos e termômetros apresentam sensibilidade, mas não senciência. (v) Animais sencientes interpretam as sensações e informações que recebem do ambiente por meio de cognição (razão) e emoções. A senciência, todavia, é uma reação mais emocional do que cognitiva às sensações. Isso faz com que um animal tenha, entre outras coisas, afeição à prole, medo de ser atacado, desgosto ao tédio e aversão ao isolamento. 0 importante disso tudo, em termos éticos, é que se um animal, considerado como um centro independente de sensibilidade ou consciência, tem estados emocionais que importam para ele mesmo, então tais estados devem importar para nós também. NACONECY, Carlos Michelon. Ética \& animais: um guia de argumentação filosófica. Porto Alegre: EdiPUCRS, 2006, p. 117.

77 Cf. REGAN, Tom. Jaulas vazias.Tradução de Regina Rheda. Porto Alegre: Lugano, 2006.

78 DUTRA, Valéria de Souza Arruda. Animais, sujeitos de direito ou sujeitosde-uma-vida? Disponível em: <http://www.publicadireito.com.br/conpedi/ manaus/arquivos/anais/salvador/valeria_de_souza_arruda_dutra-2.pdf > Acesso em: 23.mai.2017. 
animais, domésticos na maioria dos casos, cada vez mais passam a "integrar núcleos familiares", sendo,consequentemente, objetos de ações envolvendo aguarda compartilhada nas separações de casais, do mesmo modo que ocorre com as crianças. Deste modo, parece impossível se falar em guarda sem se considerar vida na melhor de suas formas.Entretanto, é contraditório que se trate um animal com zelo, mas a legislação não trate-o com a devida importância, considerando-o como coisa.

No mesmo sentido, com relação aos delitos contra a fauna, em especial o art. 32, o posicionamento doutrinário de que a coletividade é a vítima do delito não pode ser considerado correto, principalmente porque, como já mencionado, referido artigo decorre da previsão constitucional que veda a crueldade, logo, não há como se considerar vítima do delito quem não sofre, de fato, a prática $\mathrm{cruel}^{79}$.

Nesse sentido merece destaque a posição de Fernanda Luiza Fontoura de Medeiros, Jayme Weingartner Neto e Selma Rodrigues Petterle, os quais, com apoio na doutrina de Ingo Sarlet - na esfera da Teoria dos Direitos Fundamentais - e de José Rubens Moratto Leite - na seara do direito ambiental - e com o objetivo de concretizar o conteúdo e delinear os contornos básicos da dignidade em um Estado Socioambiental de Direito, propõem:

[...] uma conceituação aberta, em permanente reconstrução, para incluir a dimensão ecológica da dignidade, perspectiva multidimensional que sustenta também a dignidade da vida dos demais seres como um todo, no âmbito da dimensão objetiva dos direitos fundamentais (aqui, portanto, também incluídos os animais). ${ }^{80}$

79 TOLEDO, Maria Izabel Vasco de. op. cit., p. 12.

80 MEDEIROS, Fernanda Luiza, Fontoura de; WEINGARTNER NETO, Jayme; PETTERLE, Selma Rodrigues. op. cit., p. 30. 
Assim, essa perspectiva, mesmo que pareça utópica, demonstra-se necessária se realmente se deseja tutelar os animais de forma efetiva, principalmente em matéria penal.Para que seja alcançada, são necessárias não apenas alterações na legislação relacionada àproteção animal, mas também a realização, pela sociedade, de um exercício de consciência, a fim de que se perceba que os animais não são tão diferentes dos humanos.

\subsection{A FRAGILIDADE DAS SANÇÕES PREVISTAS NO ART. 32 DA LEI DE CRIMES AMBIENTAIS: ANÁLISE DE JULGADOS RELACIONADOS AO TEMA}

A fim de demonstrar a fragilidade das sanções previstas no art. 32 da Lei 9.605/98, realizou-se pesquisa jurisprudencial, tomando como referência condenações eventualmente impostas nos anos de 2016 e $2017^{81}$. Surpreendeu, contudo, a ínfima quantidade de julgados relacionadas a maus-tratos de animais domésticos no período referido.

Ao todo, foram localizadas apenas 2 (duas) decisões relacionadas a maus-tratos contra animais domésticos com condenação. Em contrapartida - e isso merece ser mencionado -, localizou-se, também, 1 (uma) decisão, tida como inédita no Brasil e amplamente divulgada nas mídias sociais, a qual aplicou punição modelo e pouco usual em crimes como o analisado. No entanto, em respeito à pena máxima fixada pelo art. 32 da Lei 9.605/98, não será possível a aplicação da pena integral, sendo esta reduzida ao máximo estabelecido pela Lei.

0 primeiro caso $^{82}$ analisado foi julgado pela $2^{\text {a }}$ Câmara Criminal do Tribunal de Justiça do Estado do Paraná, no início do ano

${ }_{81}$ A fonte de pesquisa utilizada foi o sítio do Jusbrasil. Disponível em: <https:// www.jusbrasil.com.br/busca?q=maus+tratos+de+animais+dom\%C3\%A9sticos>. Acesso em: 17 nov. 2017.

82 BRASIL. Tribunal de Justiça do Estado do Paraná. Apelação Crime no 15662654-PR (1566265-4). Apelante: Hercules Antonio Gonçalves Fait Junior. Apelado: Ministério Público do Estado do Paraná. Relator: Marcel Guimarães Rotoli de Macedo. Data de Julgamento: 24/11/2016. 2ª Câmara Criminal. Data de Publicação: DJ 1955 24/01/2017. 
de 2017. 0 condenado foi denunciado por praticar ato de abuso contra dois cães domésticos, ferindo-os com dois disparos de arma de fogo, causando a morte dos animais, os quais a ele "pertenciam". 0 recurso de apelação foi interposto contra a sentença penal que condenou o réu ao cumprimento da pena de 4 (quatro) meses e 2 (dois) dias de detenção e 22 (vinte e dois) dias-multa, em regime semiaberto, tendo em vista ser reincidente. 0 réu alegou estado de necessidade, afirmando que os cães teriam atacado, porém, uma vez demonstrado que os animais foram alvejados enquanto estavam presos em umcanil, localizado na residência do réu, o recurso foi improvido, à unanimidade, sendo mantida a sentença de $1^{\text {o }}$ grau em seus exatos termos.

É possível verificar, nesse julgado, que mesmotendo o maltrato ocasionado a morte de 2 (dois) animais, a pena fixada foi extremamente baixa - 4 (quatro) meses de detenção -, sendo cabível salientar, também, que o regime inicial semiaberto só foi determinado porque o condenadoé reincidente. Tal decisão, sem sombra de dúvidas, corrobora todo o exposto neste trabalho, uma vez que não parece ser considerada, na prática, a gravidade do crime, nem quando este resulta na morte injusta de 2 (dois) animais, mesmo havendo previsão expressa, no § $2^{\circ}$ do art. 32 da Lei 9.605/98, de aumento de pena - de um sexto a um terço -na hipótese de morte do animal.

0 segundo $\operatorname{caso}^{83}$ analisado foi julgado, recentemente, pela 3a Turma Criminal do Tribunal de Justiça do Distrito Federal e Territórios. 0 condenado foi denunciado por, de forma livre e consciente praticar abuso, maus-tratos e ferimento a animais domésticos, sendo uma gata e seus filhotes, gerando a morte dos

83 Tribunal de Justiça do Distrito Federal. Apelação Crime no 20150510125506-DF (0012391-78.2015.8.07.0005). Apelante: Fernando Henrique Rodrigues Cavalcante de Aguiar. Apelado: Ministério Público do Distrito Federal e Territórios. Relator: Nilsoni de Freitas Custodio. Data de Julgamento: 06/07/2017. 3ำ Turma Criminal. Data de Publicação: Publicado no DJE em 12/07/2017. Pág.: 140/146. 
animais. Na oportunidade, o condenado arremessou os animais ao seu cachorro, da raça Pitbull, que imediatamente matou todos, quebrando os seus pescoços.Orecurso de apelação foi interposto contra a sentença que condenou o réu à pena de 5 (cinco) meses e 10 (dez) dias de detenção, em regime semiaberto, e ao pagamento de 17 (dezessete) dias-multa. Considerando que o próprio réu admitiu os maus-tratos, foi negado provimento ao recurso, sendo mantida a sentença em seus exatos termos. No caso em questão não houve a substituição da pena privativa de liberdade por restritivas de direitos, uma vez ausentes os requisitos estabelecidos no art. 44 do Código Penal.

Tal como ocorreu no primeiro caso, embora o maltrato tenha resultado no óbito de mais de 1 (um) animal, em razão de o art. 32 prever penas mínima e máxima tão baixas, o agressor foi condenado em apenas 5 (cinco) meses de detenção em regime semiaberto. Não se pode, nesse sentido, afirmar que referida punição será efetiva, principalmente se considerada a extrema violência empregada pelo agressor.

É importante salientar que todos os argumentos mencionados no presente trabalho, como a não-consideração do animal como vítima do delito e a sua classificação como coisa acabam por refletir em decisões como estas, uma vez que, se fosse considerada, de fato, a dignidade da vida desses animais, a tutela teria caráter punitivo muito mais enérgico, tal como ocorre nas condenações resultantes de crimes contra a vida dos seres humanos.

Ressalta-se, nesse ponto, que não se desejacom esta afirmação colocar os animais em patamar de igualdade aos seres humanos, porém, é necessário que se compreenda a ausência da aplicação do princípio da proporcionalidade nesses casos, uma vez que o resultado "morte" é tratado de maneira excessivamente distintaentre humanos e animais. 
O caso modelo ${ }^{84}$, julgado pela $10^{\text {a }}$ Câmara de Direito Criminal do Estado de São Paulo, no mês de novembro do corrente ano, refere-se a um recurso de apelação interposto contra a sentença que condenou a ré a 12 (doze) anos, 06 (seis) meses e 14 (quatorze) dias de detenção, mais o pagamento de 444 (quatrocentos e quarenta e quatro) dias-multa. Nesse caso, a ré praticou maustratos e feriu 37 (trinta e sete) animais domésticos (cachorros e gatos), que vieram a óbito em razão desses ferimentos, bem como, visando à morte dos animais, empregou contra eles o uso de veneno (cetamina).É notória a gravidade do fato em questão principalmente porque a condenada recolhia animais em situação de abandono. Como essa vinha conseguindo lares adotivos para os animais com extrema celeridade, "as adoções" chamaram a atenção de organizações protetoras, que passaram a observá-la, até que visualizaram-na saindo de seu imóvel com 5 (cinco) sacos de lixo, dentro dos quais haviam 33 (trinta e três) cadáveres felinos e 4 (quatro) cadáveres caninos. Submetidos à perícia, em todos os corpos dos animais foram encontrados hematomas e substâncias tóxicas. Nesse caso, não apenas foi negado provimento ao recurso, mas também foi aumentada a pena para 16 (dezesseis) anos, 6 (seis) meses e 26 (vinte e seis) dias de detenção, e o pagamento de 646 (seiscentos e quarenta e seis) dias-multa.

Observa-se que, tamanha consideração dos julgadores do caso representa, certamente, um pequeno avanço na consideração da vida animal e na garantia de aplicação efetiva da tutela penal dos animais.

Durante a pesquisa notou-se, também, que existem diversas ações civis públicas ajuizadas pelos Ministérios Públicos dos Estados contra municípios que não possuem políticas públicas

84 BRASIL. Tribunal de Justiça do Estado de São Paulo. Apelação Crime no 00172472420128260050-SP (0017247-24.2012.8.26.0050). Apelante: Dalva Lina da Silva. Apelado: Ministério Público do Estado de São Paulo. Relator: Rachid Vaz de Almeida. Data de Julgamento: 09/11/2017. 10ª Câmara de Direito Criminal. Data de Publicação: 13/11/2017. 
para conter o abandono de animais domésticos, que também configura espécie de maltrato.No entanto, o intuito deste trabalho não diz respeito a esse tema, mas sim especificamente às práticas que ocorrem contra animais domésticos que estão sob a tutela de seus proprietários e afins, bem como seus respectivos resultados judiciais.

Em pesquisa ao sítio do Tribunal de Justiça do Estado do Rio Grande do Sul ${ }^{85}$ não foram localizadas decisões relevantes, a fim de fomentar a discussão proposta neste trabalho.

Por fim, a título de reflexão, é curioso verificar um número tão pequeno de decisões judiciais relacionadas ao delito, o que faz acreditar que grande parte destas ou sequer chega ao Judiciário, ou findam pela concessão de algum dos benefícios despenalizantes previstos na Lei de Crimes Ambientais.

\section{CONSIDERAÇÕES FINAIS}

Diante de todo o exposto no presente trabalho, é possível verificar a urgente necessidade de uma mudança de paradigma com relação à tutela dos animais no Direito brasileiro, principalmente no que diz respeito à aplicação da norma constitucional prevista no art. 225, $\S 1^{\circ}$, inciso VII, a qual demonstra a existência de preocupação com a vida e a integridade física dos animais, uma vez que veda práticas cruéis, visando não submetê-los ao sofrimento.

Exatamente com esse intuito, aliada à disposição do art. 225, §3ํo da Constituição de 1988, que classificou o meio ambiente - e nele incluída a fauna - com bem jurídico penal, é que foi editada a Lei de Crimes Ambientais, e sobretudo, o art. 32 da referida Lei.

No entanto, o que se verifica na prática, é que a aplicação da Lei penal não segue a diretriz imposta pela Carta Magna, uma vez que não privilegia de maneira adequada nem a integridade física, nem a vida do animal, pois prevê uma pena excessivamente

85 Pesquisa realizada no sítio do Tribunal de Justiça do Estado do Rio Grande do Sul: <http://www.tjrs.jus.br/site/>. 
baixa para a prática do delito, bem como proporciona diversas substituições à principal finalidade do Direito Penal: a aplicação da punição mais gravosa, a pena privativa de liberdade.Não bastasse esse fato ser prejudicial à tutela animal, pois acarreta, como demonstrado, em condenações baixas incapazes de exercer os caráteres punitivo e socioeducativo esperados pelo Direito Penal, ainda podem ser apontadas como agravantes à proteção animal simbólica, a visão antropocêntrica do Direito e a coisificação do animal pelo Direito Civil, que classificam, de modo semelhante, os animais como bens.

Entende-se, portanto que as hipóteses inicialmente formuladas para a pesquisa restaram confirmadas. Constatou-se que um dos fatores que fragilizam a tutela penal dos animais é a predominância do entendimento civilista que coisifica o animal. Constatou-se também que a Lei no 9.605/98, estabelece no seu art. 32, um tipo penal que não é claro ao determinar quais práticas são entendidas como maus-tratos, o que acarreta em um vazio normativo (norma penal em branco) que dificulta a repressão penal de muitas condutas abusivas e cruéis contra os animais não humanos. Percebeu-se, ainda, como salientado, que o caráter excessivamente brando das penas cominadas e os benefícios despenalizantes previstos, dificultam uma resposta penal adequada capaz de dissuadir à prática delitiva. Por fim, constatou-se que a visão antropocêntrica que ainda contamina os vasos normativos do direito ambiental brasileiro, não contribui, sobretudo na esfera penal, para uma tutela efetiva dos animais individualmente considerados, já que inviabilizam que se reconheça o animal como vítima do delito.

Assim, deixadas de lado as discussões doutrinárias, compreende-se, lamentavelmente, que a proteção dos animais contra a crueldade no Direito Penal brasileiro possui, de fato, uma carga simbólica, uma vez que todos os fatores garantidores de uma aplicação efetiva da Lei penal andam na contramão desses seres, 
dificultando e muito o respeito ao mandamento constitucional de proteção a eles dirigido.

Deste modo, se o desejo é realmente garantir a proteção dos animais contra a crueldade, considerando-os como seres vivos capazes de sentir e merecedores de uma adequada tutela penal, devem ser revistos, pelo Direito brasileiro, todos os pontos mencionados neste estudo, caso contrário, permanecerão os animaisfadados a umainfelizsimbologia protecionista.

\section{REFERÊNCIAS}

AMADO, Frederico Augusto Di Trindade. Direito ambiental esquematizado. 7a ed. rev. e atual. Rio de Janeiro: Ed. Forense. São Paulo, Ed. Método, 2016.

BRASIL. Código Civil. Lei no 10.406, de 10 de janeiro de 2002. Brasília, DF, dez. 2002. Disponível em: <http://www.planalto.gov.br/ccivil_03/ leis/2002/L10406.htm Acesso em: 21 out.2017.

. Código Penal. Decreto-Lei no 2.848, de 7 de dezembro de 1940. Rio de Janeiro, RJ, dez. 1940. Disponível em: <http://www.planalto. gov.br/ccivil_03/decreto-lei/Del2848compilado.htm> Acesso em: 02 nov.2017.

. Constituição Federal, de 05 de outubro de 1988. Brasília, DF, out. 1988. Disponível em: <http://www.planalto.gov.br/ccivil_03/constituicao/constituicao.htm> Acesso em: 12nov.2017.

. Lei de Crimes Ambientais. Lei no 9.605 de 12 de fevereiro de 1998. Brasília, DF, fev. 1998. Disponível em: <http://www.planalto.gov. br/ccivil_03/leis/L9605.htm> Acesso em: 20nov.2017.

. Projeto de Lei do Senado no 351, de 2015. Disponível em: <http:// legis.senado.leg.br/sdleg-getter/documento?dm=3530675\&disposition =inline $>$ Acesso em: 02 nov.2017

. Tribunal de Justiça do Distrito Federal. Apelação Crime no 20150510125506-DF (0012391-78.2015.8.07.0005). Apelante: Fernando Henrique Rodrigues Cavalcante de Aguiar. Apelado: Ministério Público do Distrito Federal e Territórios. Relator: Nilsoni de Freitas Custodio. Data de Julgamento: 06 jul.2017. 3a Turma Criminal. Data de Publicação: Publicado no DJE em 12 jul.2017. Pág.: 140/146. 
Tribunal de Justiça do Estado do Paraná. Apelação Crime no 15662654-PR (1566265-4). Apelante: Hercules Antonio Gonçalves Fait Junior. Apelado: Ministério Público do Estado do Paraná. Relator: Marcel Guimarães Rotoli de Macedo. Data de Julgamento: 24 nov.2016. 2a Câmara Criminal. Data de Publicação: DJ 195524 jan.2017.

. Tribunal de Justiça do Estado de São Paulo. Apelação Crime no 00172472420128260050-SP (0017247-24.2012.8.26.0050). Apelante: Dalva Lina da Silva. Apelado: Ministério Público do Estado de São Paulo. Relator: Rachid Vaz de Almeida. Data de Julgamento: 09 nov.2017. 10 a Câmara de Direito Criminal. Data de Publicação: 13 nov.2017.

CASTRO, João Marcos Adede y. Direito dos animais na legislação brasileira. Porto Alegre: Sergio Antonio Fabris Ed., 2006.

CONSTANTINO, Carlos Ernani. Delitos ecológicos: a lei comentada artigo por artigo. Aspectos penais e processuais penais. $2^{a}$ ed. São Paulo: Ed. Atlas, 2002.

DUTRA, Valéria de Souza Arruda. Animais, sujeitos de direito ou sujeitos-de-uma-vida? Disponível em: <http://www.publicadireito.com.br/conpedi/manaus/arquivos/anais/salvador/valeria_de_souza_arruda_dutra-2. pdf > Acesso em: 23mai.2017.

FIORILlO, Celso Antônio Pacheco; CONTE, Christiany Pegorari. Crimes Ambientais. São Paulo: Ed. Saraiva, 2012.

MARCÃO, Renato. Crimes ambientais (Anotações e interpretação jurisprudencial da parte criminal da Lei n. 9.605, de 12-2-1998). $2^{\text {a }}$ ed. rev., atual. e de acordo com o Novo Código Florestal (Lei n. 12.651/2012). São Paulo: Ed. Saraiva, 2013.

MEDEIROS, Fernanda Luiza, Fontoura de; WEINGARTNER NETO, Jayme; PETTERLE, Selma Rodrigues. Animais não-humanos e vedação de crueldade: o STF no rumo de uma jurisprudência intercultural. Canoas, RS: Ed. Unilasalle, 2017.

MILARÉ, Édis; COSTA JR., Paulo José da Costa; COSTA, Fernando José da. Direito penal ambiental. $2 \underline{\text { a }}$ ed. rev., atual. e ampl. São Paulo: Ed. Revista dos Tribunais, 2013.

NACONECY, Carlos Michelon. Ética \& animais: um guia de argumentação filosófica. Porto Alegre: EdiPUCRS, 2006

PRADO, Luiz Regis. Direito penal do ambiente. - 5 a ed. rev., atual. e ampl. - São Paulo: Ed. Revista dos Tribunais, 2013. 
REGAN, Tom. Jaulas vazias. Tradução de Regina Rheda. Porto Alegre: Lugano, 2006.

SANTIAGO, Alex Fernandes. Fundamentos de Direito Penal Ambiental. Belo Horizonte: Ed. Del Rey, 2015.

SILVA, Ivan Luiz da. Princípio da insignificância e os crimes ambientais. Rio de Janeiro: Ed. Lumen Juris, 2008.

SILVA, Romeu Faria Thomé da. Manual de direito ambiental. 6a ed. rev. ampl. e atual. Salvador: Ed. JusPODIVM, 2016.

SINGER, Peter. Libertação Animal. Tradução Marly Winckler e Marcelo Brandão Cipolla. São Paulo: Martin Fontes, 2010.

TEIXEIRA NETO, João Alves. Tutela penal dos animais: uma compreensão onto-antropológica. Porto Alegre: Ed. Livraria do Advogado, 2017.

TOLEDO, Maria Izabel Vasco de. A tutela jurídica dos animais no Brasil e no direito comparado. Revista Brasileira de Direito Animal, vol. 11, p. 5, jul-dez. 2012. Disponível em: <https://portalseer.ufba.br/index.php/ RBDA/article/view/8426> Acesso em 23mai.2017. 